\title{
VASCULAR AND METABOLIC RESPONSE TO STATIN IN THE MILDLY HYPERTENSIVE HYPERCHOLESTEROLEMIC ELDERLY
}

\author{
Luciola M L Crisostomo, ${ }^{\mathrm{I}}$ Carlos A M Souza, ${ }^{\mathrm{I}}$ Carlos M C Mendes, ${ }^{\mathrm{I}}$ Silmara $\mathbf{R}$

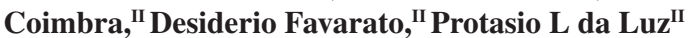

doi: $10.1590 / \mathrm{S1807-59322008000500004}$

Crisostomo LML, Souza CAM, Mendes CMC, Coimbra SR, Favarato D, da Luz PL. Vascular and metabolic response to statin in the mildly hypertensive hypercholesterolemic elderly. Clinics. 2008;63(5):589-94.

INTRODUCTION: Much evidence indicates the importance of the endothelium and hypercholesterolemia in atherosclerosis, as well as the decline in endothelial function with aging. However, it is unclear if treating dyslipidemia in elderly patients improves endothelial function and reduces C-reactive protein levels.

OBJECTIVES: To evaluate vasomotor function, lipids and C-reactive protein in mildly hypertensive and hypercholesterolemic elderly patients treated with atorvastatin.

METHODS: Forty-seven elderly Brazilian subjects ( $\geq 65$ years old) with LDL cholesterol (LDL-c) $\geq 130$ mg/dL were randomly assigned, in a double-blinded manner, to receive either placebo $(n=23)$ or $20 \mathrm{mg} /$ day of atorvastatin $(n=24)$ for 4 weeks. Exclusion criteria included diabetes, serious hypertension, obesity, steroid use, hormone replacement, and statin use within the previous six months. All patients underwent clinical examinations, laboratory tests (glucose, lipids, liver enzymes, creatine phosphokinase and high sensitivity C-reactive protein) and assessment of vasomotor function by high-resolution ultrasound examination of the brachial artery (flow-mediated dilation and sublingual nitrate), both before and after treatment.

RESULTS: The patients were 65 to 91 years old; there was no significant difference between basal flow-mediated dilation of placebo $(7.3 \pm 6.1 \%)$ and atorvastatin $(4.5 \pm 5.1 \% ; \mathrm{p}=0.20)$. The same was observed after treatment $(6.6 \pm 6.2 \mathrm{vs} .5 .0 \pm 5.6 ; \mathrm{p}$ $=0.55)$. The initial nitrate dilatation $(8.1 \pm 5.4 \%$ vs. $10.8 \pm 7.5 \% ; \mathrm{p}=0.24)$ and that after 4 week treatment $(7.1 \pm 4.7 \%$ vs. $8.6 \pm$ $5.0 \% ; \mathrm{p}=0.37)$ were similar. Atorvastatin produced a reduction of $20 \%$ of the C-reactive protein and $42 \%$ in the LDL-c; however, there were no changes in the flow-mediated dilation.

CONCLUSIONS: Atorvastatin produced a significant change of lipids and C-reactive protein; however, there were no changes in vasomotor function, suggesting the existence of intrinsic age-related vessel alterations.

KEYWORDS: Endothelium/ultrasonography; Aged; Hydroximetilglutaril-CoA reductase inhibitors; C-reactive protein; Lipid.

\section{INTRODUCTION}

Life expectancy is increasing all over the world, and similar rates are now observed in both developed and in developing countries. Aging is associated with several

\footnotetext{
${ }^{\text {I }}$ Escola Bahiana de Medicina e Saúde Pública, Universidade Federal da Bahia - Salvador/BA, Brazil.

II Unidade Clínica de Aterosclerose, Instituto do Coração (InCor), Hospital das Clínicas da Faculdade de Medicina da Universidade de São Paulo - São Paulo/SP, Brazil.

Email: daluzp@incor.usp.br

Phone: 5511 3069-5241

Received for publication on April 10, 2008

Accepted for publication on June 12, 2008
}

biological alterations in all body systems and it is associated with a high prevalence of cardiovascular diseases, which result in greater rates of hospitalization, disability and death. ${ }^{1-4}$ Aging is an independent risk factor for coronary disease $^{1,2}$ and is associated with arterial stiffness and left ventricular diastolic dysfunction, which may be responsible for symptoms such as dyspnea, fatigue and arterial hypertension. ${ }^{3-5}$ In addition to intrinsic alterations of the arterial wall, there is a decline of endothelial function with aging. ${ }^{6-12}$ When dyslipidemia occurs in the elderly, an additional mechanism may contribute to the reduced vasodilatory capacity of the arteries. However, it is not clear to what extent dyslipidemia contributes to such dysfunction. 
Previous studies have reported restoration of endothelial function and reduction of C-reactive protein (CRP) levels with the use of statins in individuals with risk factors for coronary arterial disease. ${ }^{13,14}$ However, it has not been clearly established whether treating dyslipidemia in elderly people actually improves vasomotor function and reduces CRP.

The objective of this study was to evaluate the endothelium-dependent and -independent vasodilatory response, lipid levels and CRP in mildly hypertensive hypercholesterolemic but otherwise "healthy" elderly individuals treated with atorvastatin.

\section{METHODS}

We evaluated 419 elderly people, defined as being $\geq 65$ years old, using questionnaires and medical appointments conducted during 2005, at the outpatient clinic of a University Hospital of Salvador, Bahia, Brazil. Of these, we selected 72 patients considered to be "healthy;" 47 of them had LDL cholesterol (LDL-c) $\geq 130 \mathrm{mg} / \mathrm{dL}$ and were randomized to receive either atorvastatin $(20 \mathrm{mg})$ or placebo, in a double-blind randomized placebo-controlled trial. The exclusion criteria included: diabetes, serious hypertension (systolic pressure $>190 \mathrm{~mm} \mathrm{Hg}$ and diastolic pressure > $110 \mathrm{~mm} \mathrm{Hg}$ ), obesity (BMI $\geq 30 \mathrm{~g} / \mathrm{m}^{2}$ ), heavy smoking, steroid use, hormone replacement therapy, alcoholism, kidney diseases (serum creatinine $>2 \mathrm{mg} / \mathrm{dL}$ ), liver diseases, thyroid diseases and end-stage disease, manifest coronary disease, previous stroke, ejection fraction $\leq 35 \%$, Mini Mental score $<20$ and the use of statins during the previous six months. The selected subjects were submitted to an baseline evaluation (basal) that comprised the clinical exam; Mini Mental Test; laboratory test profiles including assays for glucose, lipids, liver enzymes, creatine phosphokinase (CPK), high sensitivity CRP by means of nephelometrics; electrocardiogram (ECG), and echodopplercardiogram. Vasomotor function was evaluated by means of high resolution ultrasound assessment of the brachial artery, according to standard guidelines. ${ }^{15,16}$ The placebo group (PG $=23)$ and the atorvastatin treatment group $(\mathrm{TG}=24)$, were assigned by random computer-generated numbers. Placebo and atorvastatin $(20 \mathrm{mg}$, donated by Pfizer - Brazilian Industry) were used orally over a 30-day period. After this time, all patients underwent a second evaluation that included the clinical exam and assessments of lipids, enzymes, CRP and vasomotor function. The study was approved by the Ethical Research Committee of the institution and all patients signed an informed consent form.

The sample size was calculated for detecting a difference of one-half standard deviation in FMD in the treated group, and 20 patients were required for each arm of the study.
From previous studies in our laboratory, we expected a standard deviation of $4 \%$.

\section{Study Protocol}

Endothelium-dependent vasomotor function was evaluated through the dilation of the brachial artery, induced by reactive hyperemia (FMD); whereas endotheliumindependent dilation was induced by sublingual $5 \mathrm{mg}$ isosorbide dinitrate (NTD). Vasoactive medication was withheld for at least four half-lives of those drugs. After a fasting period of 12 hours, the patients remained at rest for $30 \mathrm{~min}$, and then they were placed in a supine position in a room with a controlled temperature between 23 and 24 degree Celsius. The brachial artery was evaluated with a high-frequency linear transducer from 7 to $12 \mathrm{MHz}$, using an ATL "Medical Systems Company" HDI 500 ultrasound system gated to ECG. The evaluation point was above the antecubital fossa of the elbow, in the longitudinal plane; where image and basal flow were recorded. The hyperemic stimuli was induced by pneumatic tourniquet inflated to $250 \mathrm{~mm} \mathrm{Hg}$ for five minutes on the arm. After deflation, hyperemic velocity was recorded at $15 \mathrm{~s}$, and images were recorded at $60 \mathrm{~s}$. After $20 \mathrm{~min}$ of rest, with the image record, dinitrate was administered and 5 min later the image recording was repeated.

The images recorded with a VCR were later used for measurements by an independent observer, using specific software that automatically identified artery borders; measurements were synchronized to the QRS of the ECG, and an average of 6 evaluated segments were used. The diameters were expressed in $\mathrm{mm}$, and the diameter variation was expressed in percentages.

\section{Statistical Analysis}

The data are presented as means, standard deviations and medians. Continuous variables, with normal distribution, were compared by Student's t-test; those variables with an asymmetric distribution, in contrast, were compared using the Mann-Whitney test, and Wilcoxon test. The interactions between sex, age group ( $<80$ and $\geq 80$ years), LDL-c ( $<160$ and $\geq 160 \mathrm{mg} / \mathrm{dL})$, BMI $(\leq 25$ and $>25 \mathrm{~kg} /$ $\left.\mathrm{m}^{2}\right)$, systolic pressure $(<140$ and $\geq 140 \mathrm{~mm} \mathrm{Hg}$ ), diastolic pressure $(<90$ and $\geq 90 \mathrm{mmHg})$ and number of risk factors $(\leq 2$ and $>2$ ) were tested by Maentel-Haenzel's $x^{2}$. Spearman's correlations were used for intra- and interobserver evaluation, and p-values $<0.05$ were considered statistically significant. The STATA software was also used in the analysis. 


\section{RESULTS}

The patients were 65-91 years old, with a mean age of 75.8 \pm 6.6 years in the placebo group, and $72.0 \pm 8.3$ years in the atorvastatin group. The patients were predominantly women (64\%). There were no significant differences regarding age, sex, race, BMI, risk factors, blood pressure, ejection fraction and glucose between the two groups (Table 1).

Prior to treatment, both groups had moderate hypercholesterolemia (LDL-c $=155.2 \pm 15.7 \mathrm{mg} / \mathrm{dL}$ in the placebo group vs. $170.1 \pm 38.9 \mathrm{mg} / \mathrm{dL}$ in the treatment group; $\mathrm{p}=\mathrm{ns}$ ), normal HDL and triglycerides. CRP, AST, ALT and CPK were also within the normal ranges for both groups (Table 2).

After treatment with atorvastatin, there was a reduction of $27 \%$ in total cholesterol, $42 \%$ in LDL-c, $20 \%$ in VLDL-c, $30 \%$ in triglycerides $(\mathrm{p}<0.05$ for all metrics); there was also a $12 \%$ increase of HDL-c, which was not statistically significant (Table 2).

In contrast, there were no significant changes in the placebo group (Table 2).

The inflammatory biomarker CRP was not different at baseline $(0.6 \mathrm{mg} / \mathrm{dL}$ vs. $0.5 \mathrm{mg} / \mathrm{dL})$. However, after 30 days, it increased to $1.1 \mathrm{mg} / \mathrm{dL}$ in the placebo group, and was reduced to $0.4 \mathrm{mg} / \mathrm{dL}$ in the atorvastatin group. That final levels of atorvastatin achieved statistically significant difference to initial atorvastastin $(p=0.02)$ and to final placebo levels ( $\mathrm{p}=0.014)$ (Figure 1).

There were no significant differences of the flow-
Table 1 - Baseline characteristics

\begin{tabular}{lcc}
\hline & Placebo & Atorvastatin \\
\hline $\mathrm{N}$ & 23 & 24 \\
Age (years) & $75.8 \pm 6.6$ & $72.0 \pm 8.3$ \\
& $(65-91)$ & $(65-90)$ \\
Men & $8(35 \%)$ & $9(38 \%)$ \\
Women & $15(65 \%)$ & $15(62 \%)$ \\
White & $7(30 \%)$ & $6(25 \%)$ \\
Non-white & $16(70 \%)$ & $18(75 \%)$ \\
BMI (kg/m²) & $25.5 \pm 3.2$ & $25.2 \pm 2.4$ \\
& $(17-29)$ & $(19-29)$ \\
Abd. Circ. $(\mathrm{cm})$ & $95.8 \pm 8.3$ & $94.0 \pm 8.6$ \\
& $(79-112)$ & $(73-110)$ \\
Risk Factor & $3(2-3)$ & $2(1-3)$ \\
SBP (mmHg) & $157.0 \pm 20.2$ & $150.0 \pm 20.7$ \\
& $(110.0-190.0)$ & $(120.0-180.0)$ \\
DBP(mmHg) & $86.0 \pm 7.1$ & $82.0 \pm 6.8$ \\
& $(75.0-100.0)$ & $(70.0-100.0)$ \\
EF (\%) & $63.6 \pm 5.5$ & $66.0 \pm 7.9$ \\
& $(52.0-72.0)$ & $(43.0-69.0)$ \\
Glucose (mg/dL) & $86.3 \pm 8.9$ & $86.6 \pm 10.5$ \\
Creatinine (mg/dL) & $(72.0-107.0)$ & $(69.0-110.0)$ \\
T4 (ng/dL) & $0.9 \pm 0.1$ & $0.9 \pm 0.2$ \\
TSH (milli-IU/mL) & $(0.7-1.2)$ & $(0.6-1.2)$ \\
\hline BMI body mas & $1.0 \pm 0.2$ & $1.1 \pm 0.2$ \\
& $(0.8-1.6)$ & $(0.8-1.5)$ \\
& $2.4 \pm 1.4$ & $2.1 \pm 0.7$ \\
& $(0.8-5.3)$ & $(0.6-5.3)$ \\
\hline
\end{tabular}

BMI: body massa index; Abd. Circ.: abdominal circumference; Risk Factor: number of risk factors; SBP: Systolic blood pressure; DBP: Diastolic blood pressure EF: ejection fraction . Data presented in absolute values, ratios, averages with standard deviations, maximum \& minimum values in parenthesis. $\mathrm{P}=\mathrm{NS}$

Table 2 - Laboratorial profile of subjects before and after treatment

\begin{tabular}{|c|c|c|c|c|}
\hline & \multicolumn{2}{|c|}{ Placebo $(n=23)$} & \multicolumn{2}{|c|}{ Atorvastatin $n=24$ ) } \\
\hline & Initial & Final & Initial & Final \\
\hline Colesterol “Total” (mg/dL) & $\begin{array}{c}231.9 \pm 23.4 \\
(193.0-279.0)\end{array}$ & $\begin{array}{c}222.8 \pm 27.6^{* * *} \\
(178.0-264.5)\end{array}$ & $\begin{array}{c}249.8 \pm 45.13 * \\
(199.0-386.1)\end{array}$ & $\begin{array}{c}161.8 \pm 30.5 * * \\
(126.3-250.4)\end{array}$ \\
\hline LDL-c (mg/dL) & $\begin{array}{c}155.2 \pm 15.7 * \\
(132.6-198.6)\end{array}$ & $\begin{array}{c}146.6 \pm 24.5^{* *} \\
(102.0-203.6)\end{array}$ & $\begin{array}{c}170.1 \pm 38.9^{*} \\
(132.6-304.5)\end{array}$ & $\begin{array}{c}84.9 \pm 26.9 * * \\
(50.2-173.0)\end{array}$ \\
\hline VLDL-c (mg/dL) & $\begin{array}{c}25.3 \pm 7.5 \\
(15.1-45.8)\end{array}$ & $\begin{array}{c}26.7 \pm 9.1 * * \\
(16.5-53.4)\end{array}$ & $\begin{array}{c}26.8 \pm 12.2 \\
(11.6-58.2)\end{array}$ & $\begin{array}{c}21.3 \pm 8.5^{* *} \\
(10.0-40.9)\end{array}$ \\
\hline HDL-c (mg/dL) & $\begin{array}{c}50.9 \pm 13.4 \\
(32.0-75.0)\end{array}$ & $\begin{array}{c}48.8 \pm 9.6 \\
(33.9-69.1)\end{array}$ & $\begin{array}{c}52.9 \pm 17.1 \\
(32.0-105.0)\end{array}$ & $\begin{array}{c}55.7 \pm 12.8 \\
(35.1-89.0)\end{array}$ \\
\hline Triglycerides (mg/dL) & $\begin{array}{c}161.2 \pm 97.6 \\
(75.7-395.0)\end{array}$ & $\begin{array}{l}162.3 \pm 98.3^{* *} \\
(82.5-394.0)\end{array}$ & $\begin{array}{c}133.0 \pm 61.2 \\
(57.9-291.1)\end{array}$ & $\begin{array}{l}106.6 \pm 42.5 * * \\
(49.9-204.4)\end{array}$ \\
\hline $\mathrm{CRP}(\mathrm{mg} / \mathrm{dL})$ & $\begin{array}{c}0.6 \pm 0.7 \\
(0.1-2.6)\end{array}$ & $\begin{array}{c}1.1 \pm 3.0^{* * *} \\
(0.1-14.6)\end{array}$ & $\begin{array}{c}0.5 \pm 0.7 \\
(0.1-3.8)\end{array}$ & $\begin{array}{l}0.4 \pm 0.9 * * \\
(0.1-4.5)\end{array}$ \\
\hline AST (U/L) & $\begin{array}{c}25.6 \pm 5.8 \\
(13.0-39.0)\end{array}$ & $\begin{array}{c}26.3 \pm 6.3 \\
(12.0-40.0)\end{array}$ & $\begin{array}{c}27.5 \pm 7.0 \\
(11.0-40.0)\end{array}$ & $\begin{array}{c}28.3 \pm 7.7 \\
(18.0-54.0)\end{array}$ \\
\hline ALT (U/L) & $\begin{array}{c}18.7 \pm 8.5 \\
(4.3-44.0)\end{array}$ & $\begin{array}{l}19.2 \pm 7.9^{* *} \\
(9.8-40.7)\end{array}$ & $\begin{array}{c}20.8 \pm 7.4 \\
(11.0-35.5)\end{array}$ & $\begin{array}{c}27.9 \pm 9.9 * * \\
(10.8-52.9)\end{array}$ \\
\hline CPK (U/L) & $\begin{array}{c}113.0 \pm 75.8 \\
(35.0-346.0) \\
\end{array}$ & $\begin{array}{c}122.0 \pm 68.4 \\
(45.0-332.0) \\
\end{array}$ & $\begin{array}{c}124.6 \pm 46.6 \\
(57.0-246.0) \\
\end{array}$ & $\begin{array}{c}133.5 \pm 62.3 \\
(40.0-258.0) \\
\end{array}$ \\
\hline
\end{tabular}

Values:mean \pm SD (minimum and maximum values). AST: aspartate aminotransferase; ALT: alanine aminotransferase; CPK: creatine phosphokinase. $p$ (initial) $=\mathrm{p}$ value before treatment; $\mathrm{p}($ final $)=\mathrm{p}$ value at the end of study. $* \mathrm{P}<0.05$ (between initial conditions): $* * \mathrm{p}<0.05$ (between final conditions) 


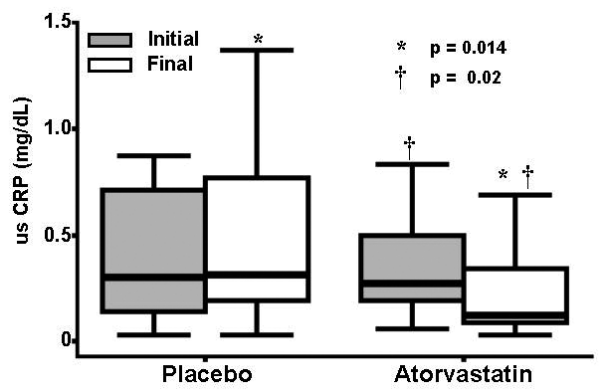

Figure 1 - Anti-inflammatory effect (hs-CRP levels) of the 4-week treatment with atorvastatin

mediated dilation and nitrate dilation at baseline or after 4 weeks in either the placebo or atorvastatin group, (Table 3 ; Figure 2). The patients presented reduced vasodilatation relative to normal controls which is over $8 \%$.

The intra- and inter-observer variation was $0.53 \%$ and there were very good correlations between inter-observer evaluations ( $\mathrm{r}=0.86$ to $0.98 \mathrm{p}<0.001)$.

Stratified analysis did not reveal significant effects of sex, age, level of LDL-c, BMI, systolic pressure, diastolic



Figure 2 - Flow Mediated Dilation (FMD) and Nitrate dilation at pre- and post-treatment (4 weeks of placebo or low dose atorvastatin) pressure and risk factor co-variables in relation to treatment with atorvastatin and vasomotor function.

After treatment, the greatest increase in liver enzymes was $<3$, and the greatest increase of CPK was $<1.5$ times the limit; no patients complained of myalgia.

\section{DISCUSSION}

We studied a group of elderly individuals, mostly women, who were apparently healthy except for moderate hypercholesterolemia and stage I systolic hypertension. They had a depressed vasodilatory arterial capacity, both endothelium-dependent and -independent. With atorvastatin treatment, $20 \mathrm{mg}$ daily for 30 days, the arterial dilatory function was not restored, despite a significant reduction of total cholesterol and LDL-c and a moderate increase of HDL-c. The stratified co-variables, such as LDL-c, sex, age, a number of risk factors, BMI, systolic and diastolic pressure, did not have a significant influence in the association of atorvastatin use and vasomotor function. There was a significant reduction of the CRP in the treatment group relative to the placebo group. The lack of change in vasodilatation may be explained by structural or functional alterations of the arteries related to senescence itself, such as a decrease of synthesis and bioavailability of nitric oxide and hardening of the arterial walls. ${ }^{4,8}$ With aging, arteries begin to thicken, and they gradually lose the capacity to distend. Studies that evaluated the viscous-elastic properties of arterial walls have shown that there are differences between the arteries of young and older people, specifically, the longitudinal retraction, the circumference increase and compliance decrease with age. ${ }^{17-19}$ Hardening of the arterial wall alters the elastic coefficient, which leads to a lower capacity of dilatation to stimulus, either by endogenous or exogenous nitric oxide. ${ }^{17}$ Other studies have found larger FMD and NTD values, but the limits of the patients' age were below those of the present study. ${ }^{11-16,20,21,24}$ Several studies have reported improvement of vasomotor function

Table 3 - Brachial artery diameters, flow mediated dilation (FMD) and nitrate dilatation (NTD) before and after treatment

\begin{tabular}{lcccc}
\hline & \multicolumn{2}{c}{ Placebo $(\mathrm{n}=23)$} & \multicolumn{2}{c}{ Atorvastatin $(\mathrm{n}=24)$} \\
& Initial & Final & Initial & Final \\
\hline Basal $(\mathrm{mm})$ & $4.1 \pm 0.4(3.2-5.0)$ & $4.0 \pm 0.4(3.2-4.9)$ & $4.1 \pm 0.7(3.0-5.8)$ & $4.0 \pm 0.6(3.0-5.6)$ \\
Hyperemia $(\mathrm{mm})$ & $4.4 \pm 0.4(3.7-5.1)$ & $4.3 \pm 0.4(3.6-5.3)$ & $4.2 \pm 0.7(2.9-5.7)$ & $4.3 \pm 0.7(3.1-6.2)$ \\
Pre Nitrate $(\mathrm{mm})$ & $4.4 \pm 0.4(3.4-5.2)$ & $4.3 \pm 0.5(3.6-5.2)$ & $4.1 \pm 0.7(2.9-5.9)$ & $4.2 \pm 0.7(3.2-5.8)$ \\
Nitrate $(\mathrm{mm})$ & $4.7 \pm 0.5(3.9-6.3)$ & $4.6 \pm 0.4(3.9-5.5)$ & $4.6 \pm 0.7(3.4-6.4)$ & $4.6 \pm 0.8(3.4-6.4)$ \\
FMD $(\%)$ & $7.3 \pm 6.1(0.2-17.7)$ & $6.2 \pm 6.2(-4.8-23.7)$ & $4.5 \pm 5.1(-3.8-18.7)$ & $5.0 \pm 5.6(-5.1-18.9)$ \\
NTD $(\%)$ & $8.1 \pm 5.4(1.0-21.2)$ & $7.1 \pm 4.7(-1.3-21.1)$ & $10.8 \pm 7.5(1.9-36.5)$ & $8.6 \pm 5.0(1.4-21.6)$ \\
\hline
\end{tabular}

() range 
with some interventions, including statins. ${ }^{13,22-24}$ However, studies comparing elderly people to younger ones that used atorvastatin for 6 weeks, also reported no restoration of vasomotor function. ${ }^{25}$ Another explanation for no amelioration of vasodilator response may be the need for a longer treatment period or higher dose of atorvastatin.

The significant reduction of CRP detected in the present study emphasizes the possibility of anti-inflammatory action of the statins. ${ }^{26,27}$ This is important because inflammation has been consistently observed at different stages of atherosclerosis. On the other hand, the presence of CRP has been demonstrated in atherosclerotic lesions; additionally, high concentrations of inflammation markers, CRP among others, in apparently healthy subjects, have been shown to be predictive of future vascular events. ${ }^{27,28}$ The observed reduction of lipid and HDL-c levels are in agreement with other studies. ${ }^{29-33}$ It is worth noting that the elderly patients in our study presented good tolerance to the treatment, considering the absence of clinical manifestations related to the atorvastatin use and the non-significant variation of $\mathrm{CPK}$ and liver enzymes.

Because there is no consensus about treatment of dyslipidemia in the elderly; this study allowed for the evaluation of reduction levels of lipids and CRP upon vasomotor function in elderly patients. Evidently, the absence of a significant effect of atorvastatin upon arterial dilation does not preclude the use of statins in the elderly since reduction of dyslipidemia and inflammation are important by themselves, indeed those actions may be responsible for the beneficial effects observed with statin administration in other studies. . $^{13,23,31-33}$

There are limitations in the present study that are related to the selection of the population and the small sample size. However, this was intended as a short-term study in which clinical outcomes were not evaluated, and sample size was calculated only to detect a difference of one-half standard deviation between the two groups; this necessitated having just 20 patients in each group.

\section{CONCLUSION}

Despite a significant reduction in lipids and CRP, there were no significant changes in vasomotor function, suggesting that intrinsic alterations of the vessel are associated with old age.

\section{REFERENCES}

1. Kannel WB, Dawber TR, Kagan A, Revotskie N, Stokes III J. Factors of risk in the development of coronary heart disease-six year follow-up experience: the Framingham study. Ann Intern Med. 1961;55:30-50.

2. Gordon T, Kannel WB, Castelli WP. Lipoproteins cardiovascular disease and death: The Framingham Study. Arc Intern Med. 1981;141:112831 .

3. Ravaglia G, Forti P, Maioli F, Boachi F, Cicognani A, Bernardi M et al. Determinants of functional status in healthy Italian nonagenarians and centenarians: a comprehensive functional assessment by the instruments of geriatric practice. J Am Geriatr Soc. 1997;45:1196-202.

4. Lakatta GE, Levy D: Arterial and cardiac aging: shareholders in cardiovascular disease enterprises: Part II: The aging heart in health: Links to heart disease. Circulation. 2003;107:346-54.

5. Stevens J, Jianwen C, Pamuk ER, Williamson DF, Thun MJ, Wood JL. The effect of age on association between body-mass index and mortality, N Engl J Med. 1998;338:1-7.

6. Furchgott RF \& Zawadzki JV. The obligatory role of endothelial cells in the relaxation of arterial smooth muscle by acetylcholine. Nature. 1980;288:373-6.

7. Ludmer PL, Selwyn AP, Shook TL. Paradoxal vasoconstriction induced by acetylcholine in atherosclerotic coronary arteries. $\mathrm{N}$ Eng J Med. 1986;315:1046-51.

8. Furchgott RF. The discovery of endothelium-derived relaxing factor and is importance in the identification of nitric oxide. JAMA. 1996;276:11868 .
9. Ridker PM, Cushman M, Stampfer J, Iracy RP, Hennekens CH. Inflammation, aspirin, and the risk of cardiovascular disease in apparently healthy men. N Engl J Med. 1997;336:973-9.

10. Ross R. Atherosclerosis-an inflammatory disease. N Engl J Med. 1999,340:115-26.

11. Celemajer DS, Sorensen KE, Spiegelhater DJ, Geogakopoulos JR, Deanfield JE. Aging Is Associated With Endothelial Dysfunction in Healthy Men Years Before the Age-Related Decline in Women. J Am Coll Cardiol. 1994;24:471-6.

12. Yataco AR, Corretti MC, Gardner AW, Womack CJ, Katzel LI. Endothelial reactivity and cardiac risk factors in older patients with peripheral arterial disease. Am J Cardiol. 1999;83:754-8.

13. Dupois J, Tardif JC, Cernacek P, Théroux P. Cholesterol reduction rapidly improves endothelial function after acute coronary syndromes - The RECIFE (Reduction of Cholesterol in Ischemia and Function of the Endothelium) Trial. Circulation. 1999; 99:3227-33.

14. Haelst PL van, Doormaal JJ van, Asselbergs FW, Asselbergs FW, van Roon AM, Veeger NJGM et al. Correlates of endothelial function and their relationship with inflammation in patients with familial hypercholestelolaemia. Clinical Science. 2003;104:627-32.

15. Corretti MC, Anderson TJ, Benjamin EJ, Celermajer D, Charboneau F, Creager MA, et al. Guidelines for the Ultrasound Assessment of Endothelial-Dependent Flow-Mediated Vasodilation of the Brachial Artery. A Report of the International Brachial Artery Reactivity Task Force. J Am Coll Cardiol. 2002;39:257-65. 
16. Coimbra SR, Lage SH, Brandizzi L, Yoshida V, da Luz PL. The action of red wine and purple grape juice on vascular reactivity is independent of plasma lipids in hipercholesterolemic patients. Braz J Med Res. 2005;38:1339-47.

17. Peterson LH, Jensen RE, Parnell MS. Mechanical Properties of Arteries in Vivo. Circulation Research. 1960; 8:622-39.

18. Learoyd BM and Taylor MG. Alterations with Age in the Viscoelastic Properties of Human Arterial Walls. Circulation Research. 1966;28:27892.

19. Avolio AP, Chen SG, Wang RP, Zhang CL, Li MF, O'Rourke MF. Effects of aging on changing arterial compliance and left ventricular load in a northern Chinese urban community. Circulation. 1983;68:50-8.

20. Schroeder S, Enderle MD, Baumbach A, Ossen R, Herdeg C, Kuettner $\mathrm{A}$, et al. Influence of vessel size, age and body mass index on the flow-mediated dilatation (FMD\%) of brachial artery. Int J Cardiol. 2000;76:219-25.

21. Herrington DM, Drum M, Riley WA, Pusser BE, Crouse JR, Burke GL et al. Brachial flow-mediated vasodilator responses in populationbased research: methods, reproducibility and effects of age, gender and baseline diameter. J Cardiovasc Risk. 2001;8:319-28.

22. Anderson TJ, Meredith IT, Yeung AC, Frei B, Selwyn AP, Ganz P. The effect of cholesterol-lowering and antioxidant therapy on endotheliumdependent coronary vasomotion. N Eng J Med. 1995;332:488-93.

23. Beckman JA, Liao JK, Hurley S, Garrett LA, Chui D, Mitra D, et al. Atorvastatin Restore Endothelial Function in Normocholesterolemic Smokers Independent of Changes in Low-Density Lipoprotein. Circulation Research. 2004;95:217-23.

24. Benjó AM, Maranhão RC, Coimbra SR, Andrade AC, Favarato D, Molina MS, et al. Accumulation of chylomicron remnants impaired vascular reactivity occur in subjects with isolated low HDL cholesterol: effects of niacin treatment. Atherosclerosis. 2006;187:116-22.
25. Weverling-Rijnsburger AWE, Blauw GJ, Meinders AE. Effect of atorvastatin on impaired vascular function in healthy old men. J Clin Pharm Ther. 2004;29:157-64.

26. Mozaffarian D, Minami E, Letterer RA, Lawler RL, McDonald GB, Levy WC. The Effects of Atorvastatin(10mg) on Systemic Inflammation in Heart Failure. Am J Cardiol. 2005;96:1699-704.

27. Cushman M, Arnold AM, Psaty BM, Manolio TA, Kuller LH, Burke GL, et al. C-Reactive Protein and the 1-Year Incidence of Coronary Heart Disease in Older Men and Women. Circulation. 2005;112:25-31.

28. Ridker PM, Hennekens CH, Buring JE, Rifai N. C-reactive protein and other markers of inflammation in the prediction of cardiovascular disease in women. N Engl J Med. 2000;342:836-43.

29. Libby P, Ridker PM, Maseri A. Inflammation and atherosclerosis. Circulation. 2002;105:1135-43.

30. Shepherd J, Blauw GJ, Murphy MB, Ballen ELEM, Buckley BM, Cobbe $\mathrm{SM}$, et al. Pravastatin in elderly individuals at risk of vascular disease (PROSPER): a randomized controlled trial. Lancet. 2002;360:162330.

31. Nissen SE, Tuzcu EM, Schoenhagen P, Brown BG, Ganz P, Vogel RA, Crowe T, Howard G, Cooper CJ, Brodie B, Grines CL, DeMaria AN. Effect of Intensive Compared with Moderate Lipid-Lowering Therapy on Progression of Coronary Atherosclerosis (REVERSAL): A Randomized Controlled Trial. JAMA. 2004;291:1071-80.

32. LaRosa JC, Grundy SM, Waters DD, Shear C, Bater P, Fruchart JC, et al. Intensive Lipid Lowering with Atorvastatin in Patients with Stable Coronary Disease (TNT). N Engl J Med. 2005;352:1425-35.

33. Newman C, Tsai J, Szarek M, Luo D, Gibson E. Comparative Safety of Atorvastatin $80 \mathrm{mg}$ Versus 10mg. Derived from Analysis of 49 Completed Trials in 14,236 Patients. Am J Cardiol. 2006;97:61-7. 